\title{
The Effects of the Social Hierarchy Destabilization on the Foraging Activity of Eusocial Wasp Mischocyttarus cerberus styx Richards, 1940 (Hymenoptera: Vespidae: Polistinae)
}

\author{
Vanderlei Conceição Costa Filho, Sulene Noriko Shima, \\ Ivan Cesar Desuó, and André Sunao Nishiuchi Murakami \\ Departamento de Zoologia, Instituto de Biociências, UNESP, Avenida 24-A, 1515, 13506-900 Rio Claro, SP, Brazil \\ Correspondence should be addressed to Vanderlei Conceição Costa Filho, vccfilho@gmail.com
}

Received 23 February 2011; Revised 11 April 2011; Accepted 5 June 2011

Academic Editor: Felipe Andrés León Contrera

Copyright (C) 2011 Vanderlei Conceição Costa Filho et al. This is an open access article distributed under the Creative Commons Attribution License, which permits unrestricted use, distribution, and reproduction in any medium, provided the original work is properly cited.

\begin{abstract}
The genus Mischocyttarus comprises 245 species of neotropical basal eusocial wasps. They form small colonies (rarely more than few tens of individuals); castes are morphologically undifferentiated and determined behaviorally by agonistic interactions. The aim of this study was to verify the effects of the experimental disruption of social hierarchy on foraging activity of Mischocyttarus cerberus styx. We observed six colonies in postemergence phase and recorded data on the foraging activity under two experimental conditions: (1) removal of lower-ranked females and (2) removal of higher ranked females, except the queen. Our results showed that the removal of higher-ranked females had higher effect on the number of foraging trips of $M$. cerberus styx than the removal of lower-ranked females (the number of foraging trips/hour decreased by $66.4 \%$ and $32.7 \%$, resp.). Such results are likely due to the social organization of this species and the presence of a distinct class of females, which in this study were regarded as intermediates. Our data also showed that, irrespective of the hierarchical status of the females, the removal of two or three individuals affected significantly the number of foraging trips in this species.
\end{abstract}

\section{Introduction}

The tribe Mischocyttarini is arranged in a single genus (i.e., Mischocyttarus) with 245 species [1,2]. This group of basal, eusocial wasps is widely distributed in South America, and only two species occur in southern and western of the United States $[3,4]$.

The colonies of Mischocyttarus are founded independently or by an association of few females, and castes are morphologically undifferentiated. The social organization of this group is determined by agonistic interaction which leads to the establishment of a dominance hierarchy $[3,5]$. Queens occupy the highest rank in the social hierarchy. They are responsible for egg-laying, whereas workers perform other tasks such as brood care, nest defense, and foraging [5-8]. Since caste determination is mainly behavioral, the social roles of females of Mischocyttarus are flexible. Tradeoffs and superseding of queens are common features in the social hierarchy $[3,9]$. Bruyndonckx et al. [10] carried out experimental manipulations on Ropalidia marginata and suggested that dominance and subordination interactions, beyond social control, also act as a signal for workers to collect more food. Physiological conditions of females, such as the amount of fat body and ovarian development, are positively related to the dominance rank in Mischocyttarus cassununga $[11,12]$. Litte [13] verified that when the queens of Mischocyttarus mexicanus were removed the non-egglaying foundresses were capable of developing their ovaries and started to lay eggs one week after the queen's removal. Similar results were found by Field and Foster [14] in Liotenogaster flavolineata, in which helper females began to lay eggs when queens were experimentally removed. 
TABLE 1: Characteristics of the studied colonies in the beginning/end of the observations.

\begin{tabular}{cccccccc}
\hline Colony & Hours of observations & Number of cells & Eggs & Larvae & Pupae & Females $^{1}$ & Males $^{2}$ \\
\hline M14 & 30 & $30 / 31$ & $8 / 9$ & $10 / 13$ & $6 / 5$ & $5 / 2$ & $1 / 0$ \\
M15 & 30 & $52 / 53$ & $7 / 7$ & $11 / 12$ & $11 / 12$ & $6 / 2$ \\
M16 & 30 & $59 / 61$ & $20 / 13$ & $22 / 24$ & $7 / 7$ & $6 / 0$ \\
M17 & 30 & $70 / 71$ & $19 / 11$ & $21 / 24$ & $5 / 7$ & $5 / 2$ \\
M18 & 30 & $22 / 22$ & $1 / 3$ & $13 / 11$ & $5 / 4$ & $5 / 2$ & $5 / 2$ \\
M19 & 30 & $46 / 46$ & $11 / 12$ & $13 / 16$ & $4 / 5$ & $5 / 2$ & $1 / 0$ \\
\hline
\end{tabular}

${ }^{1}$ Two females (one of colony M15 and another of colony M16) disappeared during premanipulation observations and were not considered in the data sets, thus in the end of the manipulations the same number of individuals were left in each colony.

${ }^{2}$ Males which emerged or were seen during the observations were immediately removed from the nests.

O'Donnell [15] argued that workers of Polistes differed in their behavior according to a set of physical and social stimuli, intrinsic (social and developmental) or extrinsic (environmental). These behavioral switches are necessary to maintain reasonable levels of food and pulp collection according to the needs of the colony.

The wasp Mischocyttarus cerberus styx builds stelocyttarus, gymnodomous nests, and the colonies are populated by a few individuals [16]. Interestingly, Silva [17] firstly described a distinct class of females which were classified neither as foragers nor as dominant females. According to the author these females were characterized by resting the most part of their time in the back side of the comb and occasionally collecting and distributing the food; however, no further information on the social role of these females was provided in this study.

The aim of this study was to verify the effects of the experimental removal of females in different hierarchical positions upon the foraging activity of Mischocyttarus cerberus styx and to investigate the critical number of females necessary to maintain reasonable levels of foraging activity and prevent the colony from declining.

\section{Material and Methods}

The study was carried out from March to May 2010 in 6 postemergence colonies of Mischocyttarus cerberus styx (Table 1). These colonies were observed at the campus of São Paulo State University (UNESP), Rio Claro, São Paulo, Brazil $\left(22^{\circ} 24^{\prime} 26^{\prime \prime} S ; 47^{\circ} 33^{\prime} 36^{\prime \prime} \mathrm{W}\right)$. All adults were marked with nontoxic acrylic paint to identify their position in the social hierarchy before the start of the observations.

The hierarchical position was determined by the dominance-subordination interactions of each female in the colonies. Dominance behaviors were defined as a female investing physically against another by attacking, biting, chasing, pecking, or holding wings or legs using the mandibles $[3,10]$. This method of hierarchy establishment was widely used by several authors $[5,6,8,9,11,12$, $18,19]$. In order to provide a better female categorization a set of other behaviors were recorded and analyzed: (1) permanence in the nest (in minutes), (2) foraging activity, (3) cell inspection, and (4) rubbing the gaster against the nest wall: the female typically rubs the ventral part of its gaster along the stem and upper part of the comb, this behavior is associated with the defense against ants as tested by Jeanne [6]. The base of the terminal portion of the gaster bears a tuff of hairs that carries a glandular secretion which avoids ants to reach the wasp's brood [20].

To carry out this study six colonies were observed by 6 hours a day for 5 consecutive days, totaling 180 hours of observation. Observations were taken daily from 9:00 to 12:00 and from 14:00 to 17:00. The foraging activity was recorded when foragers landed in the nest carrying liquids or prey items. Then, foraging activity is herein defined as the act of bringing prey and liquids to the nest. As stated by Hunt [21] liquids can be described as nectar, nectar-like fluids, and body fluids of prey. In this study we also included water, once as it is extremely important to the maintenance of physiological activities of the individuals, thermoregulation, and building of the nest.

Initially the manipulations were taken by removing 50 and $75 \%$ of individuals of each colony. Such procedure was carried out in four colonies (M10, M11, M12, and M13). However, in these four colonies even the removal of $50 \%$ of individuals caused the abandon of individuals from the nest. Based on this previous test we concluded that the abrupt removal of females of Mischocyttarus cerberus styx led to the colony decline and abandon of females. Thus, a new approach based on gradual removal of the individuals in different hierarchical positions was conducted as follows.

(1) During 12 hours (day 1 and day 2) the dominance hierarchy was determined and we also collected data on the foraging trips. This period represented the control observations (no manipulations).

(2) At the end of the second day of observation, the first female was removed, and the data on the foraging trips was collected during day 3 . At the end of day 3 the second female was removed, and data collection took place during day 4 . Finally, at the end of day 4 the last female was removed from the nest, and the data collection occurred during day 5 .

(3) In the first three colonies (M15, M16, and M17) only the lowest-ranked individuals were removed, whereas in the other colonies (M14, M18, and M19) only the highest-ranked individuals were removed except the queen. On the last day of observation, only two individuals were left in each colony. The colonies 
TABle 2: Dominance and subordination behaviors (\% absolute number) of each individual by colony during the determination of dominance hierarchy.

\begin{tabular}{|c|c|c|c|c|c|}
\hline \multirow{2}{*}{$\begin{array}{l}\text { Colony } \\
\text { M14 }\end{array}$} & \multicolumn{5}{|c|}{ Rank } \\
\hline & $1^{\mathrm{a}}$ & $2^{\mathrm{a}}$ & $3^{\mathrm{a}}$ & $4^{a}$ & $5^{\mathrm{a}}$ \\
\hline Dominance & $94.6(35)$ & $5.4(2)$ & $0.0(0)$ & $0.0(0)$ & $0.0(0)$ \\
\hline Subordination & $0.0(0)$ & $48.7(18)$ & $43.2(16)$ & $5.4(2)$ & $2.7(1)$ \\
\hline M15 & $1^{\mathrm{a}} / \mathrm{Q}$ & $2^{\mathrm{a}} / \mathrm{I}$ & $3^{\mathrm{a}} / \mathrm{W}$ & $4^{\mathrm{a}} / \mathrm{W}$ & $5^{\mathrm{a}} / \mathrm{W}$ \\
\hline Dominance & $93.9(31)$ & $6.1(2)$ & $0.0(0)$ & $0.0(0)$ & $0.0(0)$ \\
\hline Subordination & $0.00(0)$ & $66.7(22)$ & $6.1(2)$ & $6.1(2)$ & $21.2(7)$ \\
\hline M16 & $1^{\mathrm{a}} / \mathrm{Q}$ & $2^{\mathrm{a}} / \mathrm{I}$ & $3^{\mathrm{a}} / \mathrm{I}$ & $4^{\mathrm{a}} / \mathrm{W}$ & $5^{\mathrm{a}} / \mathrm{W}$ \\
\hline Dominance & $76.1(35)$ & $10.9(5)$ & $10.9(5)$ & $2.1(1)$ & $0.0(0)$ \\
\hline Subordination & $0.0(0)$ & $39.1(18)$ & $41.3(19)$ & $10.9(5)$ & $8.7(4)$ \\
\hline M17 & $1^{\mathrm{a}} / \mathrm{Q}$ & $2^{\mathrm{a}} / \mathrm{I}$ & $3^{\mathrm{a}} / \mathrm{W}$ & $4^{\mathrm{a}} / \mathrm{W}$ & $5^{\mathrm{a}} / \mathrm{W}$ \\
\hline Dominance & $90.0(36)$ & $10.0(4)$ & $0.0(0)$ & $0.0(0)$ & $0.0(0)$ \\
\hline Subordination & $0.0(0)$ & $40.0(16)$ & $27.5(11)$ & $10.0(4)$ & $22.5(9)$ \\
\hline M18 & $1^{\mathrm{a}} / \mathrm{Q}$ & $2^{\mathrm{a}} / \mathrm{I}$ & $3^{\mathrm{a}} / \mathrm{W}$ & $4^{\mathrm{a}} / \mathrm{W}$ & $5^{\mathrm{a}} / \mathrm{W}$ \\
\hline Dominance & $80.0(24)$ & $20.0(6)$ & $0.0(0)$ & $0.0(0)$ & $0.0(0)$ \\
\hline Subordination & $0.0(0)$ & $70.0(21)$ & $16.7(5)$ & $0.00(0)$ & $13.3(4)$ \\
\hline M19 & $1^{\mathrm{a}} / \mathrm{Q}$ & $2^{\mathrm{a}} / \mathrm{I}$ & $3^{\mathrm{a}} / \mathrm{I}$ & $4^{\mathrm{a} / W}$ & $5^{\mathrm{a}} / \mathrm{W}$ \\
\hline Dominance & $100.0(2)$ & $0.0(0)$ & $0.0(0)$ & $0.0(0)$ & $0.0(0)$ \\
\hline Subordination & $0.0(0)$ & $50.0(1)$ & $50.0(1)$ & $0.0(0)$ & $0.0(0)$ \\
\hline Total & $1^{\mathrm{a}} / \mathrm{Q}$ & $2^{\mathrm{a}} / \mathrm{I}$ & $3^{\mathrm{a} / \mathrm{I}}$ & $4^{\mathrm{a} / W}$ & $5 / \mathrm{W}$ \\
\hline Dominance & $86.7(163)$ & $10.1(19)$ & $2.7(5)$ & $0.5(1)$ & $0.0(0)$ \\
\hline Subordination & $0.0(0)$ & $51.1(96)$ & $28.7(54)$ & $6.9(13)$ & $13.3(5)$ \\
\hline
\end{tabular}

M15 and M16 had originally 6 individuals each; however, during the control observations, one individual of each colony disappeared by unknown causes and were not considered in the analyzes. Therefore, at the end of the manipulations in these two colonies, like in the other ones, only two individuals remained in the nest. It is also important to mention that the two different manipulations were never carried out in the same colony. We studied six colonies, and, in three of them, we followed only with the removal of higher-ranked females and in the other three we only removed the lower-ranked females.

The statistics were conducted using STATISTICA 8.0 and SAS 9.2 statistical software packages. Once we spent 12 hours collecting data during the control and 6 hours for each treatment the absolute numbers of foraging trips were converted into frequency per hour. In order to achieve normality the data was transformed using Box-Cox Transformation. We used K-S Lilliefors and Levene's statistics to test normality and variance homoscedasticity, respectively. Since the tests revealed that the data were normally distributed $(d=0.16$, $P=0.15)$ and the variances were homogeneous $(F=1.44$, $P=0.26$ ), a one-way ANOVA was chosen to test the effects of the experimental removal of different-ranked females against control observations. We used Dunnett's $t$-test to perform post hoc means comparisons to a control treatment (no experimental manipulation). The same procedures were used to test the effect of the number of removals on the foraging activity of Mischocyttarus cerberus styx.

\section{Results and Discussion}

3.1. Determination of Dominance Hierarchy. The percentages of dominance and subordination behaviors of each female by each colony are shown in Table 2. Among all the females of each colony the queens performed the higher percentage $(86.7 \%)$ of dominance interactions and were not subordinated by any other female of the colony. The intermediate-ranked females (2nd and 3rd individuals of the hierarchy rank) may also perform dominance interactions; however, in a much lower percentages than the queens (10.1 and $2.7 \%$, resp.). These individuals, however, are constantly attacked by the queens (they received 51.1 and $28.7 \%$ of all subordination acts). On the other hand, the lower-ranked females (the 4th and 5th individuals in the hierarchy rank, resp.) performed no aggressive acts towards any individual of the colony and also received few dominance interactions from higher-ranked individuals (6.9 and 13.3\%, resp.).

The percentages/absolute number of a set of important behaviors related to the determination of the dominance hierarchy of Mischocyttarus cerberus styx are shown in Table 3. According to these results the time spent in the colony by each individual is proportional to its position in the social hierarchy: queens remained the most part of the time in the nest (95\% of total time observation), followed by the intermediate-ranked females (2nd and 3rd females, 78 and $70 \%$, resp.) and the lower-ranked individuals (4th and 5 th individuals, 32 and $21 \%$, resp.).

The higher percentages of agonistic interaction received by the intermediate-ranked females (Table 2) may be 
TABle 3: Time in the nest $(T)$ of foraging activities $(F)$, cell inspection $(C)$, and gaster rubbing $(R)$ of all individuals by colony during the determination of dominance hierarchy.

\begin{tabular}{|c|c|c|c|c|c|}
\hline & \multirow{2}{*}{ Category/ranking } & \multirow{2}{*}{$T(\min )$} & \multicolumn{3}{|c|}{$\%$ of behaviors by colony (absolute number) } \\
\hline & & & $F$ & C & $R$ \\
\hline \multirow{5}{*}{ Colony M14 } & $1^{\mathrm{a}}$ & 720 & $0.0(0)$ & $42.3(11)$ & $64.9(24)$ \\
\hline & $2^{a}$ & 317 & $35.3(6)$ & $19.2(5)$ & $27.0(10)$ \\
\hline & $3^{\mathrm{a}}$ & 643 & $17.7(3)$ & $26.9(7)$ & $2.7(1)$ \\
\hline & $4^{\mathrm{a}}$ & 137 & $29.4(5)$ & $11.5(3)$ & $5.4(2)$ \\
\hline & $5^{\mathrm{a}}$ & 31 & $17.7(3)$ & $0.0(0)$ & $0.0(0)$ \\
\hline \multirow{5}{*}{ Colony M15 } & $1^{\mathrm{a}}$ & 719 & $0.0(0)$ & $32.6(14)$ & $25.8(16)$ \\
\hline & $2^{\mathrm{a}}$ & 619 & $8.3(1)$ & $34.9(15)$ & $33.9(21)$ \\
\hline & $3^{\mathrm{a}}$ & 415 & $25.0(3)$ & $7.0(3)$ & $14.5(9)$ \\
\hline & $4^{\mathrm{a}}$ & 350 & $33.3(4)$ & $11.6(5)$ & $17.7(11)$ \\
\hline & $5^{\mathrm{a}}$ & 260 & $33.3(4)$ & $14.0(6)$ & $8.1(5)$ \\
\hline \multirow{5}{*}{ Colony M16 } & $1^{\mathrm{a}}$ & 720 & $0.0(0)$ & $35.9(14)$ & 45.7 (16) \\
\hline & $2^{a}$ & 720 & $0.0(0)$ & $10.3(4)$ & $25.7(9)$ \\
\hline & $3^{\mathrm{a}}$ & 690 & $0.0(0)$ & $28.2(11)$ & $14.3(5)$ \\
\hline & $4^{\mathrm{a}}$ & 298 & $33.3(5)$ & $15.4(6)$ & $2.9(1)$ \\
\hline & $5^{\mathrm{a}}$ & 123 & $66.7(10)$ & $10.3(4)$ & $11.4(4)$ \\
\hline \multirow{5}{*}{ Colony M17 } & $1^{\mathrm{a}}$ & 523 & $0.0(0)$ & $44.0(11)$ & $35.7(10)$ \\
\hline & $2^{\mathrm{a}}$ & 423 & $18.2(2)$ & $20.0(5)$ & $10.7(3)$ \\
\hline & $3^{\mathrm{a}}$ & 342 & $9.1(1)$ & $28.0(7)$ & $17.9(5)$ \\
\hline & $4^{\mathrm{a}}$ & 148 & $45.5(5)$ & $4.0(1)$ & $7.1(2)$ \\
\hline & $5^{\mathrm{a}}$ & 122 & $27.3(3)$ & $4.0(1)$ & $28.6(8)$ \\
\hline \multirow{5}{*}{ Colony M18 } & $1^{\mathrm{a}}$ & 712 & $0,0(0)$ & $33,3(0)$ & $33,3(4)$ \\
\hline & $2^{a}$ & 720 & $0,0(0)$ & $25,0(3)$ & $25,0(3)$ \\
\hline & $3^{\mathrm{a}}$ & 358 & $16,7(2)$ & $0,0(0)$ & $8,3(1)$ \\
\hline & $4^{\mathrm{a}}$ & 216 & $41,7(5)$ & $16,7(2)$ & $16,7(2)$ \\
\hline & $5^{\mathrm{a}}$ & 186 & $41,7(5)$ & $33,3(4)$ & $58,3(7)$ \\
\hline \multirow{5}{*}{ Colony M19 } & $1^{\mathrm{a}}$ & 720 & $0.0(0)$ & $43.5(20)$ & $31.5(17)$ \\
\hline & $2^{\mathrm{a}}$ & 586 & $10.0(1)$ & $17.4(8)$ & $20.4(11)$ \\
\hline & $3^{\mathrm{a}}$ & 569 & $20.0(2)$ & $15.2(7)$ & $14.8(8)$ \\
\hline & $4^{\mathrm{a}}$ & 245 & $20.0(2)$ & $6.5(3)$ & $3.7(2)$ \\
\hline & $5^{a}$ & 392 & $50.0(5)$ & $17.4(8)$ & $29.6(16)$ \\
\hline \multirow{5}{*}{ Total (\%) } & $1^{\mathrm{a}}$ & 95 & $0,0(0)$ & $40,0(74)$ & $37,3(87)$ \\
\hline & $2^{a}$ & 78 & $13,0(10)$ & $21,6(40)$ & $24,5(57)$ \\
\hline & $3^{\mathrm{a}}$ & 70 & $16,9(13)$ & $16,8(31)$ & $12,4(29)$ \\
\hline & $4^{\mathrm{a}}$ & 32 & $31,2(24)$ & $9,2(17)$ & $8,6(20)$ \\
\hline & $5^{\mathrm{a}}$ & 21 & $39,0(30)$ & $12,4(23)$ & $17,2(40)$ \\
\hline
\end{tabular}

TABLe 4: One-Way ANOVA results for the removal of females according to the social rank (control: no experimental manipulation, manipulation 1: removal of lower-ranked females, and manipulation 2: removal of higher-ranked females).

\begin{tabular}{|c|c|c|c|c|c|}
\hline \multirow[b]{2}{*}{ Effects } & \multicolumn{5}{|c|}{ One-Way ANOVA } \\
\hline & Df & Anova SS & Mean square & $F$ value & $P$ \\
\hline Manipulation & 2 & 2.44 & 1.22 & 10.14 & $<0.001$ \\
\hline Error & 21 & 2.51 & 0.12 & & \\
\hline
\end{tabular}

Post hoc comparisons (Dunnett's $t$-test)

Control versus manipulation 1

Control versus manipulation $2 * * *$

*** Significance at the 0.05 level. 
TABLE 5: Female category, ranking position, absolute frequency of egg-laying, and oophagy behaviors observed for each colony during the observation.

\begin{tabular}{|c|c|c|c|}
\hline & Category/ranking & Egg-laying & Oophagy \\
\hline \multirow{5}{*}{ Colony M14 } & Queen $/ 1^{\mathrm{a}}$ & 5 & 1 \\
\hline & Intermediate $/ 2^{\mathrm{a}}$ & 1 & 2 \\
\hline & Intermediate $/ 3^{\mathrm{a}}$ & 0 & 1 \\
\hline & Worker $/ 4^{\mathrm{a}}$ & 0 & 0 \\
\hline & Worker $/ 5^{\mathrm{a}}$ & 0 & 0 \\
\hline \multirow{5}{*}{ Colony M15 } & Queen/1 ${ }^{\mathrm{a}}$ & 2 & 1 \\
\hline & Intermediate $/ 2^{\mathrm{a}}$ & 1 & 1 \\
\hline & Worker $/ 3^{\mathrm{a}}$ & 0 & 0 \\
\hline & Worker $/ 4^{\mathrm{a}}$ & 0 & 0 \\
\hline & Worker $/ 5^{\mathrm{a}}$ & 0 & 0 \\
\hline \multirow{5}{*}{ Colony M16 } & Queen/1 ${ }^{\mathrm{a}}$ & 2 & 0 \\
\hline & Intermediate $/ 2^{\mathrm{a}}$ & 0 & 0 \\
\hline & Intermediate $/ 3^{\mathrm{a}}$ & 2 & 2 \\
\hline & Worker $/ 4^{\mathrm{a}}$ & 0 & 1 \\
\hline & Worker $/ 5^{\mathrm{a}}$ & 0 & 0 \\
\hline \multirow{5}{*}{ Colony M17 } & Queen $/ 1^{\mathrm{a}}$ & 1 & 1 \\
\hline & Intermediate $/ 2^{\mathrm{a}}$ & 0 & 1 \\
\hline & Worker $/ 3^{\mathrm{a}}$ & 0 & 0 \\
\hline & Worker $/ 4^{\mathrm{a}}$ & 0 & 0 \\
\hline & Worker $/ 5^{\mathrm{a}}$ & 0 & 0 \\
\hline \multirow{5}{*}{ Colony M18 } & Queen $/ 1^{\mathrm{a}}$ & 0 & 0 \\
\hline & Intermediate $/ 2^{\mathrm{a}}$ & 0 & 0 \\
\hline & Worker $/ 3^{\mathrm{a}}$ & 0 & 0 \\
\hline & Worker $/ 4^{\mathrm{a}}$ & 0 & 0 \\
\hline & Worker $/ 5^{\mathrm{a}}$ & 0 & 0 \\
\hline \multirow{5}{*}{ Colony M19 } & Queen $/ 1^{\mathrm{a}}$ & 3 & 1 \\
\hline & Intermediate $/ 2^{\mathrm{a}}$ & 0 & 0 \\
\hline & Intermediate $/ 3^{\mathrm{a}}$ & 1 & 1 \\
\hline & Worker $/ 4^{\mathrm{a}}$ & 0 & 0 \\
\hline & Worker $/ 5^{\mathrm{a}}$ & 0 & 0 \\
\hline
\end{tabular}

explained by the behavioral role displayed by these females in the social scenario. Intermediate-ranked females exhibit typical dominance behaviors spending a large amount of the time in the nest performing relatively high percentages of cell inspection (21.6 and 16.8\%, resp.) and gaster rubbing (24.3 and $12.4 \%$, resp.) (Table 3 ). In colony M16 the queen and the 2 nd ranked female remained in the nest during all the observation period, and in colony M18 the 2nd ranked female spent even more time in the nest than the queen (Table 3). Although these females remain a large amount of the time in the nest, as the queens, they typically occupy different positions in the comb. While the queens occupy mostly the front face of the comb right above the pupae, the intermediate-ranked females typically rest at the back face of the comb; such differences in the nest position of the different ranked females were also observed in Polistes canadensis [8]. The intermediate-ranked females also contribute to the foraging activity (13 and $16.9 \%$, resp.) of the colony, and only in colonies M16 and M18 there are no records for food collection by these females. On the other hand, the lower-ranked individuals spent more time in the field collecting prey and liquids and performed a higher number of foraging trips/hour (31.2 and 39\%, resp.).

According to the behavioral repertoire showed by the females which occupied the 2nd and 3rd positions in the social rank they cannot be exactly classified as nonworkers of Polistes fuscatus [8] since they also contribute to the food intake of the colony and perform behaviors highly associated with dominance (e.g., cell inspection and gaster rubbing) (Table 3). Gadagkar and Joshi [18] found three different categories of females based on behavioral repertoire: sitters, fighters and foragers. Sitters were represented by the queens and other non-egg-laying females which did little or no foraging and rarely exhibited defense behavior. The author stated that these non-egg-laying females could represent replacement queens or naive workers. Table 3 showed that the intermediate-ranked females (2nd and $3 \mathrm{rd}$ positions) were responsible for a considerable portion $(29.9 \%)$ of the total foraging trips recorded in this study, different than what was found for the nonworkers of Polistes fuscatus and for the sitters of Ropalidia marginata [18, 22]. In this context, the "sitters" are more likely to be compared to the dominant females of $M$. cerberus styx and the intermediates to the "fighters" of Ropalidia marginata. However, we observed that the intermediate females attacked each other much less frequently than was found among the "fighter" of Ropalidia marginata, and the dominant females were considerably more aggressive towards the intermediates than were the "sitters" against the "fighters." As stated by Gadagkar and Joshi [18] the "fighters" could also reach the status of an egg-layer if the colonies of Ropalidia marginata become large and polygynous or if the queen disappears. In fact, Table 5 showed that the intermediate-ranked females and the queen could be competing for reproduction through differential oophagy. In this context, in the absence of queens (due to natural causes, such as predation or senescence and death) the intermediate females of $M$. cerberus styx would have more chances to assume the post of principal egglayer than typical foragers, as occuring in Polistes fuscatus and Polistes canadensis [8]. Such comparisons indicate that, despite some similarities in the social organization of Polistes, Ropalidia, and Mischocyttarus, the different ranked females behaves differently according to the taxa and generalizations on the social roles of each group of females are difficult, especially if these groups of wasps are commonly compared in different regions and climates and are commonly under different environmental constrains. Similar results to these found in the present study were also found by Murakami [19], Murakami and Shima [9, 11], and Murakami et al. [12] in Mischocyttarus cassununga.

Based on the results showed above the females of $M$. cerberus styx were classified as follows.

(1) Queen: it spends most of her time in the comb and occupies the front face of the comb and usually rests right above the pupae; it is the first female to request 


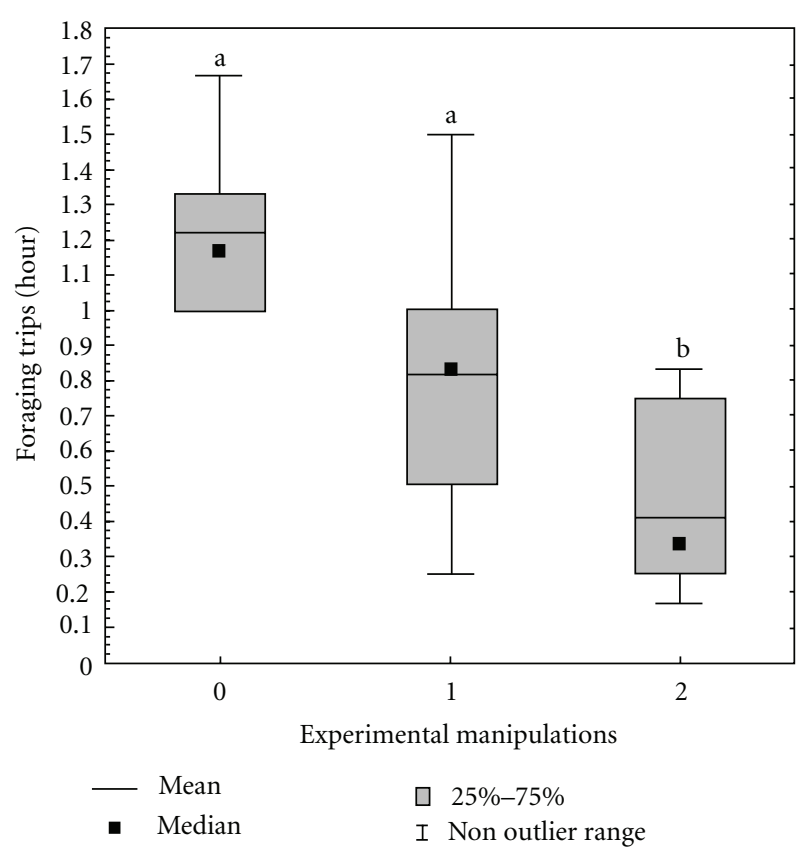

Figure 1: Box-plots indicating the means, median, 25th and 75th percentiles and non-outlier range of the data set used to compare the effect of the removals of females according to the hierarchical position. When compared with the control (0), only the removal of higher-ranked females decreased significantly the foraging activity of Mischocyttarus cerberus styx (0: no manipulation; 1: removal of lower-ranked females and 2: removal of higher-ranked females). Statistical significance at the level of 0.05 .

food from foragers; it is usually the most aggressive individual of the colony.

(2) Intermediate females: they spend most of their time resting in the back side of the comb and usually occupy the 2nd or 3rd positions of the social rank. They present intermediary behavior between queens and foragers: they perform high frequencies of cell inspection and gaster rubbing, as the queens [16]; however, they also forage. These female may also lay eggs, even in the presence of the queen (Table 5).

(3) Workers or foragers: they spend most of their time in the field collecting food and liquids.

3.2. Experimental Manipulations. The results showed that both experimental removals of individuals decreased the foraging activity of Mischocyttarus cerberus styx (Table 4; Figure 1). However, the effects proved to be statistically significant only when higher-ranked females were removed. No statistical difference was found when lower-ranked females were taken away (Table 4; Figure 1). Although the gradual removals of the females could create a dilutive effect during the manipulations, the entire experiment was conducted in the very same conditions (the two different treatments were never carried out in the same colony, the same number of removals were performed in each colony, and the colonies were analyzed in the same phase of development and with

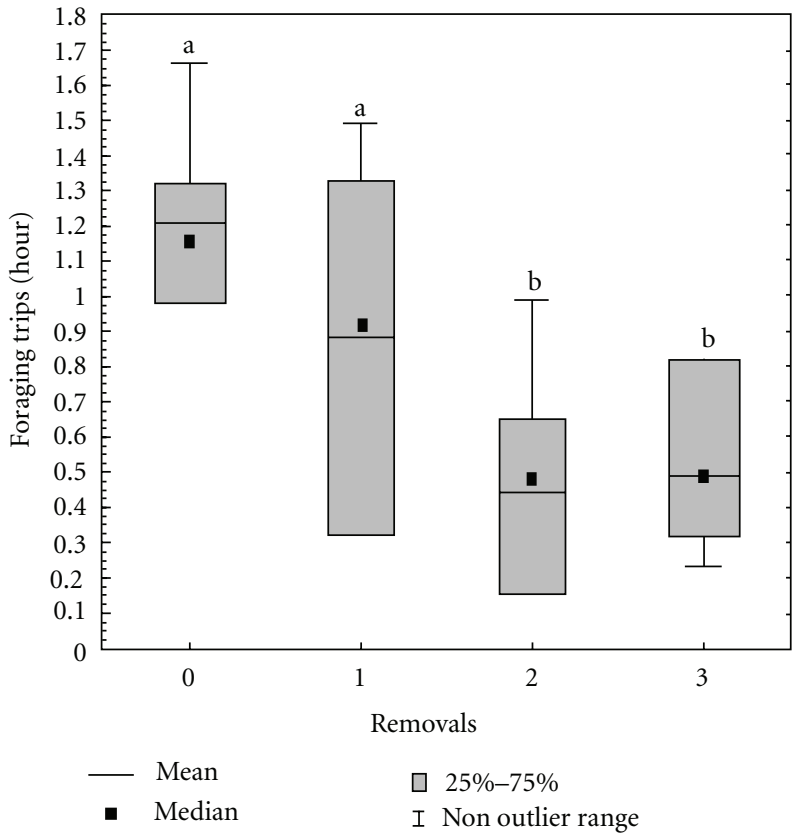

Figure 2: Box-plots indicating the means, median, 25th and 75 th percentiles and non-outlier range of the data set used to compare the effect of the number of removals regardless the female hierarchical position. When compared with the control (0), the removal of 2 or 3 females, regardless of their social position, decreased significantly the mean number foraging trips/hour of Mischocyttarus cerberus styx ( 0 : no manipulation; 1 : removal of 1 female; 2: removal of 2 females; 3 : removal of 3 females). Statistical significance at the level of 0.05 .

the same number of individuals), ensuring the consistence of the collected data. Furthermore, as cited in Section 2 the abrupt removal of females led to the abandon of the colony in $100 \%$ of attempts, colonies M10, M11, M12, and M13. Most importantly is that the social hierarchy system showed by this species may explain these results.

According to Silva [17], females that occupy the second and third positions in the hierarchical ranking usually exhibit the intermediate behavior. As previously described, these females remain most of their time resting in the back side of the comb performing dominance behaviors and also contributing to foraging activity (Table 3 ). We found that these females competed with the queens for the reproductive control of the colony, either by oophagy or by laying eggs in empty honeycomb cells (Table 5). Unlike the queen's substitutes described by Litte [13] the intermediate females of $M$. cerberus styx may lay eggs even in the presence of the queen.

This intermediate behavior may provide to these females the possibility of saving energy, which would be primarily spent on foraging trips and other tasks. This individual would have a much higher chance of assuming the position of an egg layer than a regular forager. Actually, in 5 out of the 6 colonies observed (M14, M15, M16, M17, and M19) we recorded oophagy by individuals that were not the queen, and in 4 of them (M14, M15, M6, and M19) 
TABLE 6: One-Way ANOVA results for the removal of females regardless of their social rank (control: no manipulation; treatment 1: removal of 1 female, treatment 2: removal of 2 females, and, treatment 3: removal of 3 females).

\begin{tabular}{|c|c|c|c|c|c|}
\hline \multirow[b]{2}{*}{ Effects } & \multicolumn{5}{|c|}{ One-Way ANOVA } \\
\hline & Df & Anova SS & Mean square & $F$ value & $P$ \\
\hline Removal & 3 & 1.61 & 0.54 & 5.68 & 0.0056 \\
\hline Error & 20 & 1.89 & 0.10 & & \\
\hline \multicolumn{6}{|c|}{ Post hoc comparisons (Dunnett's $t$-test) } \\
\hline \multicolumn{6}{|l|}{ Control versus $1^{r}$ removal } \\
\hline \multicolumn{6}{|l|}{ Control versus $2^{r}$ removal ${ }^{* * *}$} \\
\hline Control versus $3^{r}$ removal $^{* * *}$ & & & & & \\
\hline
\end{tabular}

we observed more than one individual laying eggs (Table 5). These behaviors were considered as an indicative of intense competition among females because, in most cases, before the oviposition, the intermediate female fed on the egg previously laid in the same cell, even with several empty cells available in the nest.

In the situation that intermediate females (typically the 2nd and 3rd females of the social rank) were removed experimentally, a typical forager assumed the post of intermediate immediately after the removal. Thus, besides the removal of an intermediate female, which also contributes to food collection (Table 3), there was also the loss of a typical forager which began to remain more time in the nest and to forage less. This dramatically reduced the daily number of food trips in the colonies observed (Figure 2). These results demonstrate the importance of the maintenance of social hierarchy in colonies of Mischocyttarus cerberus styx. According to Strassmann and Meyer [22], the maintenance of dominance hierarchy reduces considerably the conflicts for queen replacement when she disappears.

The removal of lower-ranked females did not affect the amount of foraging trips statistically (Table 4, Figure 1). As the dominance hierarchy was not disrupted, no rearrangement in the dominance rank was necessary and the remaining foragers continued food collection normally. Only when most of foragers were removed the intermediate females started to behave as typical foragers, spending more time collecting, and this may explain the reason that the removal of foragers did not affect significantly the foraging activity of $M$. cerberus styx.

O'Donnell [15] showed that the removal of foragers of Polistes instabilis decreased the rate of foraging activities, but it also resulted in the recruitment of new individuals to carry out the tasks affected. Robinson [23] argued that colonies of social insects respond to intrinsic and environmental changes by adjusting the ratio of working force allocated in the different tasks. Although Mischocyttarus cerberus styx have shown some flexibility when all foragers were removed, it is very unlikely that females recruitment occurs in this species, since it has a small population and may not have enough individuals to be reallocated for different tasks. Thus, the loss of few individuals in this species may prevent colonies to continue developing. In fact, our data showed that the removal of 2 or 3 individuals, regardless of their social position, decreased significantly the number of foraging trips/hour (Table 6; Figure 2). To perform such analysis we isolated the effect of the removals based on the hierarchical position, since the prime objective here was to investigate the critical number of removals which would affect significantly the number of foraging trips/hour in M. cerberus styx. The results obtained were not a surprise for this species since it has a few individuals per colony and a single female in a colony of 5 nest mates representing $20 \%$ of the total population and 2 or 3 individuals representing respectively, 40 and $60 \%$ of the entire colonial population.

Finally, we concluded that (1) the foraging activity of the colonies of Mischocyttarus cerberus styx is more sensitive to the removals of higher ranked females than foragers since such treatment caused the disruption of the social hierarchy and forced a rearrangement in the social roles of females decreasing significantly the number of foraging trips/hour; (2) in this species, no evident recruitment of new individuals to perform foraging trips was observed after the experimental manipulations, possibly because of the small colonial population in this species; (3) the removal of 2 or 3 individuals, regardless the social rank, could bring serious implications to the food intake of the colony as it affected significantly the number of foraging trips/hour. In fact, our preliminary tests showed that the abrupt removal of at least $50 \%$ of the colony individuals led to the abandon of females preventing the colony from continuing developing.

This study represents the first step towards a better understanding of how the eusocial basal Mischocyttarus deals with internal conflicts and how these colonies adapt themselves to new social scenarios. Moreover, we approached for the first time the existence and probable role of intermediate females in neotropical basal eusocial wasps.

\section{Acknowledgments}

The authors acknowledge the financial support by FAPESP (Fundação de Amparo à Pesquisa do Estado de São Paulo) (Grant no. 2008/57399-4) and Matheus Rigobelo Chaud (local expert in correction of scientific text for publication).

\section{References}

[1] J. M. Carpenter, "Biogeographic patterns in the Vespidae (Hymenoptera): two views of Africa and South America," in Biological Relationships between Africa and South America, 
P. Goldblatt, Ed., pp. 139-155, Yale University Press, New Haven, Conn, USA, 1993.

[2] O. T. Silveira, "Phylogeny of wasps of the genus Mischocyttarus de Saussure (Hymenoptera, Vespidae, Polistinae)," Revista Brasileira de Entomologia, vol. 52, no. 4, pp. 510-549, 2008.

[3] R. Gadagkar, "Belonogaster, Mischocyttarus, Parapolybia and independent founding Ropalidia," in The Social Biology of Wasps, K. G. Ross and R. W. Matthews, Eds., pp. 149-190, Cornell University Press, Ithaca, NY, USA, 1991.

[4] O. W. Richards, The Social Wasps of the Americas, Excluding Vespinae, British Museum Natural History, London, UK, 1978.

[5] P. Pardi, "Dominance order in Polistes wasps," Physiological Zoology, vol. 21, pp. 1-13, 1948.

[6] R. L. Jeanne, "Social biology of Neotropical wasps Mischocyttarus drewseni," Bulletin of Museum of Comparative Zoology, vol. 144, no. 3, pp. 63-150, 1972.

[7] H. K. Reeve, "Polistes," in The Social Biology of Wasps, K. G. Ross and R. W. Matthews, Eds., pp. 149-190, Cornell University Press, Ithaca, NY, USA, 1991.

[8] M. J. West-Eberhard, The Social Biology of Polistinae Wasps, vol. 14, Miscellaneous Publications of the Museam Zoology, Michigan, Mich, USA, 1969.

[9] A. S. N. Murakami and S. N. Shima, "Nutritional and social hierarchy establishment of the primitively eusocial wasp Mischocyttarus cassununga (Hymenoptera, Vespidae, Mischocyttarini) and related aspects," Sociobiology, vol. 48, no. 1, pp. 183-207, 2006.

[10] N. Bruyndonckx, S. P. Kardile, and R. Gadagkar, "Dominance behaviour and regulation of foraging in the primitively eusocial wasp Ropalidia marginata (Lep.) (Hymenoptera: Vespidae)," Behavioural Processes, vol. 72, no. 1, pp. 100-103, 2006.

[11] A. S. N. Murakami and S. N. Shima, "Factors regulating social hierarchy during the development of colonies of the primitively eusocial wasp Mischocyttarus (Monocyttarus) cassununga, Von Ihering, 1903 (Hymenoptera,Vespidae)," Journal of the Kansas Entomological Society, vol. 83, pp. 163-171, 2010.

[12] A. S. N. Murakami, S. N. Shima, and I. C. Desuó, "More than one inseminated female in colonies of the independent-founding wasp Mischocyttarus cassununga von Ihering (Hymenoptera, Vespidae)," Revista Brasileira de Entomologia, vol. 53, no. 4, pp. 653-662, 2009.

[13] M. Litte, "Behavioral ecology of the social wasp, Mischocyttarus mexicanus," Behavioral Ecology and Sociobiology, vol. 2, no. 3, pp. 229-246, 1977.

[14] J. Field and W. Foster, "Helping behaviour in facultatively eusocial hover wasps: an experimental test of the subfertility hypothesis," Animal Behaviour, vol. 57, no. 3, pp. 633-636, 1999.

[15] S. O’Donnell, "Effects of experimental forager removals on division of labour in the primitively eusocial wasp Polistes intabilis (Hymenoptera: Vespidae)," Behaviour, vol. 135, no. 2, pp. 173-193, 1998.

[16] E. Giannotti, "Social organization of the eusocial wasp Mischocyttarus cerberus (Hymenoptera, Vespidae)," Sociobiology, vol. 33, no. 3, pp. 325-338, 1999.

[17] I. M. D. Silva, Diferenciação etológica e morfofisiológica das castas Mischocyttarus cerberus styx Richards, 1940 (Hymenopetra, Vespidae, Mischocyttarini), com especial referência à dinâmica do estabelecimento da hierarquia social, M.S. thesis, Universidade Estadual Paulista, Campus de Rio Claro, SP, Brazil, 2007.

[18] R. Gadagkar and N. V. Joshi, "Quantitative ethology of social wasps: time-activity budgets and caste differentiation in
Ropalidia marginata (Lep.) (Hymenoptera: Vespidae)," Animal Behaviour, vol. 31, no. 1, pp. 26-31, 1983.

[19] A. S. N. Murakami, Diferenciação etológica e morfofisiológica das castas de Mischocyttarus (Monocyttarus) cassununga von Ihering, 1903 (Hymenoptera,Vespidae,Mischocyttarini), com especial referência às fêmeas hierarquicamente superiores, M.S. thesis, Universidade Estadual Paulista, Campus de Rio Claro, SP, Brazil, 2007.

[20] J. van der Vecht, "The terminal gastral sternite of female and worker social wasps (Hymenoptera, Vespidae)," Proceedings of the Koninklijke Nederlandse Akademie van Wetenschappen, vol. 71, pp. 411-422, 1968.

[21] J. H. Hunt, "Nourishment and the evolution of the social vespidae," in The Social Biology of Wasps, G. K. Ross and R. W. Matthews, Eds., pp. 426-450, Comstock, Ithaca, NY, USA, 1991.

[22] J. E. Strassmann and D. C. Meyer, "Gerontocracy in the social wasp, Polistes exclamans," Animal Behaviour, vol. 31, no. 2, pp. 431-438, 1983.

[23] G. E. Robinson, "Regulation of division of labor in insect societies," Annual Review of Entomology, vol. 37, no. 1, pp. 637-665, 1992. 



Submit your manuscripts at

http://www.hindawi.com
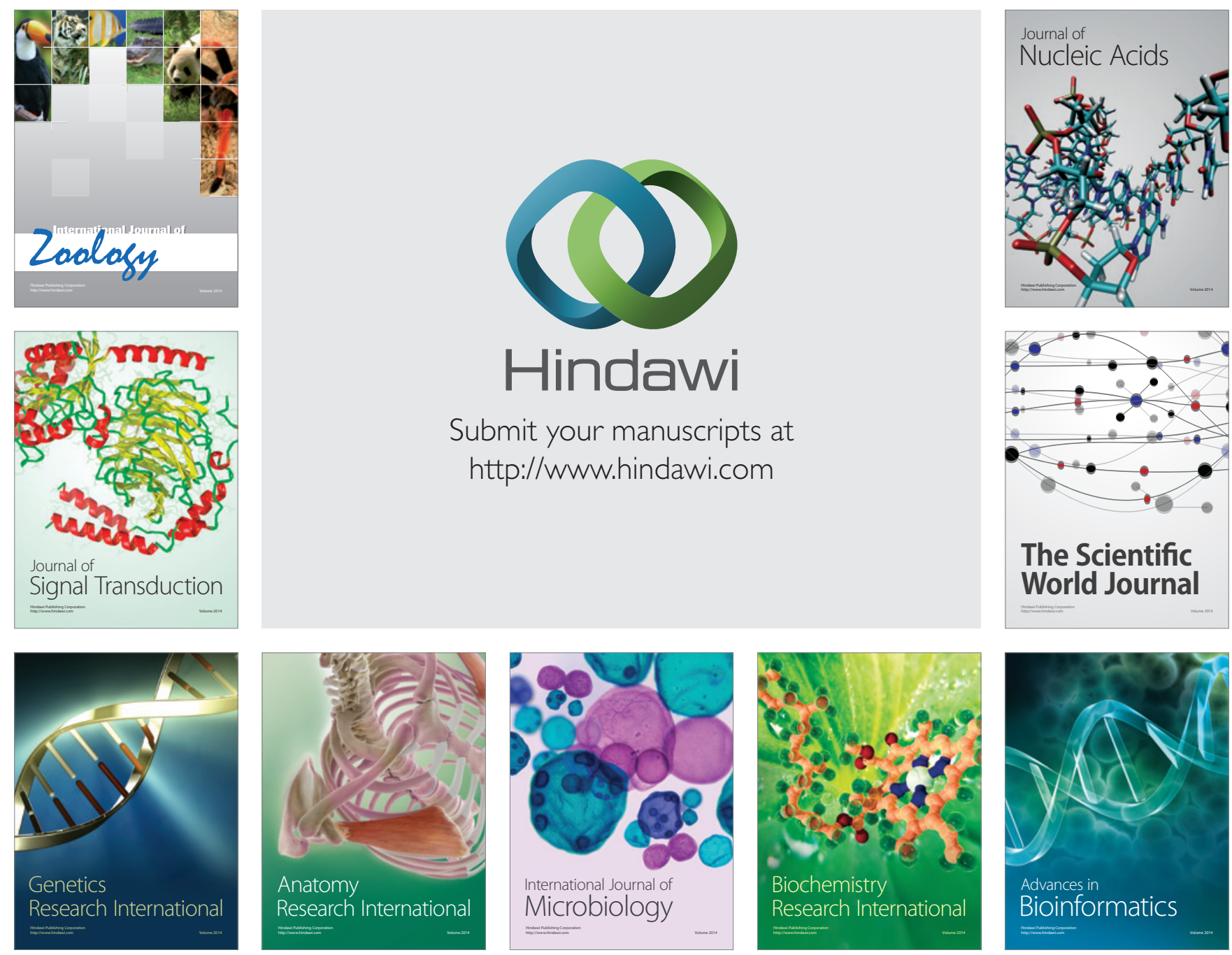

The Scientific World Journal
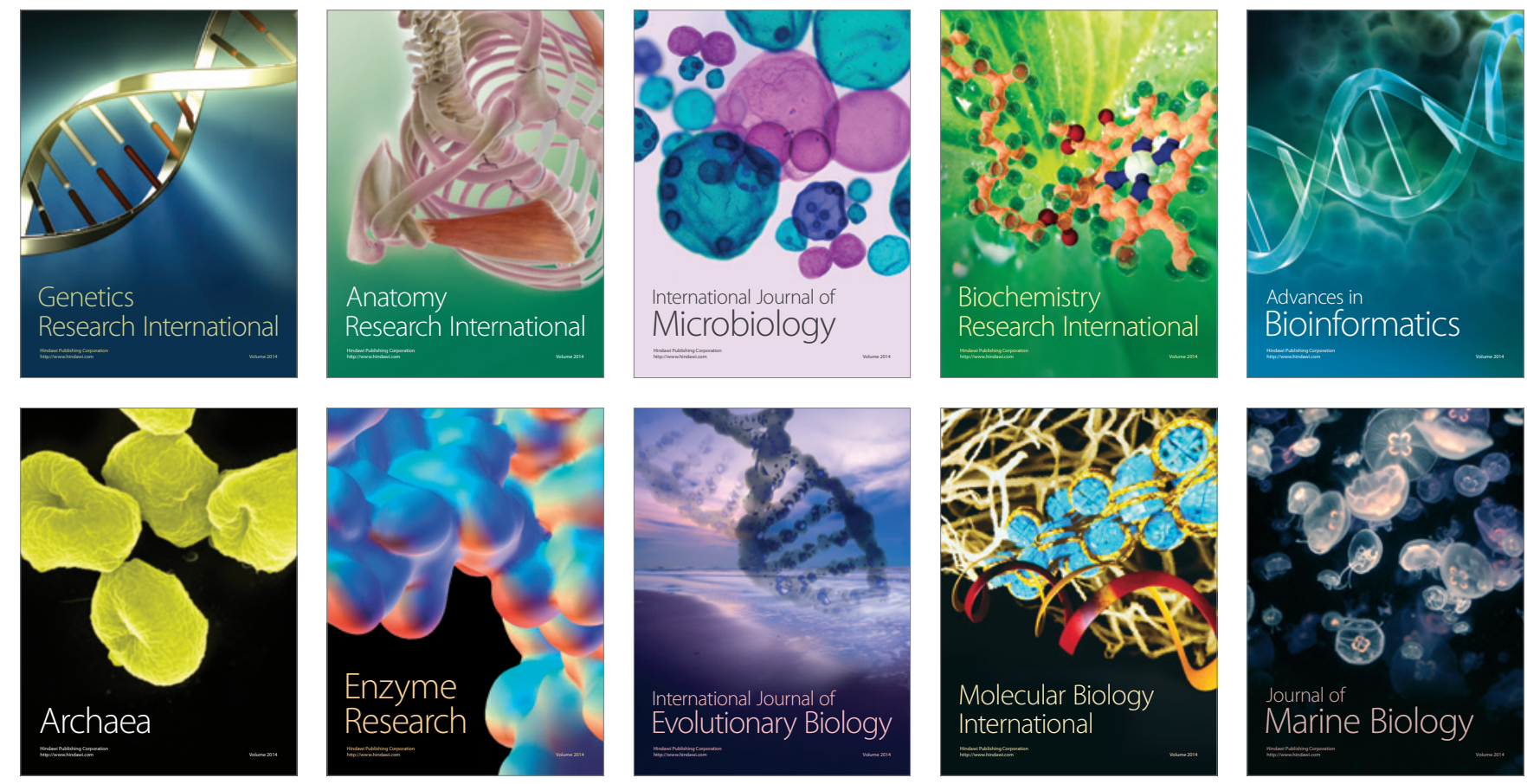